\title{
Content of macronutrients in the plant residues of winter wheat while minimizing primary tillage
}

\author{
Dmitry Dubovik ${ }^{1 *}$,Elena Dubovik ${ }^{1}$, Alexander Shumakov ${ }^{1}$, and Bogdan Roik ${ }^{1}$ \\ ${ }^{1}$ Kursk Federal Agricultural Research Center, 70 b, Karl Marx st., Kursk, 305021, Russia
}

\begin{abstract}
As a result of the research, the influence of primary tillage practices (plowing, combined tillage, surface tillage, direct sowing) was studied on the accumulation of nitrogen, phosphorus and potassium in plant residues in the soil, in the straw and grain of winter wheat, under the conditions of chernozem soils of Kursk Region. The balance of macronutrients coming from plant residues was calculated. It was found that in the spring period in the soil layer $0-20 \mathrm{~cm}$ under winter wheat there was more undecayed plant residues when subsoil practices of primary tillage were used. At the same time, as the depth of tillage decreased, a large mass of plant residues was concentrated in the upper $0-10 \mathrm{~cm}$ layer of the soil. By the harvest period, there was an increase in the amount of plant residues in the soil by 2.96-4.62 $\mathrm{t} / \mathrm{ha}$. At the same time, the highest indicators were observed in case of plowing and direct sowing 4.62 and $4.53 \mathrm{t} / \mathrm{ha}$, respectively. The highest reserves of nitrogen and potassium in undecayed plant residues under winter wheat in the soil were found when using direct sowing $(36.0 \mathrm{~kg} / \mathrm{ha})$, those of phosphorus when plowing $(10.5 \mathrm{~kg} / \mathrm{ha})$ was used in the soil layer of 0 $10 \mathrm{~cm}$. The highest mass of winter wheat straw was formed against the background of plowing $(6.2$ $\mathrm{t} / \mathrm{ha})$, while the content of phosphorus and potassium in it was the highest $(0.26 \%$ and $1.10 \%$, respectively). The highest yield of winter wheat grain was formed against the background of plowing (4.40 t/ha), the lowest yield was with direct sowing (3.26 t/ha). Without the use of mineral fertilizers, a negative balance of macronutrients was formed.
\end{abstract}

\section{Introduction}

Biologization of agricultural technologies is the basis for preventing soil degradation and reproduction of soil fertility [1]. An important role in this is played by the use of plant residues of crops [2,3]. Plant residues contribute to the reproduction of organic matter in the soil [4], serve as a means of forming the soil structure [5], and are a source of mineral nutrition elements [6]. At the same time, the entering into the soil of a large mass of plant residues, which are by-products of crop production, largely depends on the method of primary tillage [7]. Thus, during the moldboard plowing of the soil, they are relatively evenly distributed over the arable horizon, and in case of surface tillage they are placed mainly in the upper layer of the soil (up to $10 \mathrm{~cm}$ ). With an extreme degree of minimization of tillage, i.e. direct sowing, the by-product remains not embedded in the soil and serves as a mulching layer [8]. Plant residues that are not embedded in the soil take longer to decompose, which prevents the soil from replenishing with nutrients. In the absence or lack of mineral fertilizers, this increases the negative balance of macronutrients in the soil.

The aim of the work was to determine the level of nitrogen, phosphorus and potassium in plant residues using various methods of primary tillage, and to assess the balance of these macronutrients in typical chernozem as well.

\section{Materials and methods}

The research was carried out in the field stationary experiment of Kursk Federal Agricultural Research Center (Kursk Region, Kursk District, Cheryomushki settl.) in 2019-2020 in a four-field crop rotation. The second cycle of the crop rotation was started with the following alternation of crops: peas-winter wheatsoybean-barley.

The design of the experiment included the following variants: moldboard plowing $(20-22 \mathrm{~cm})$; combined tillage (disking 8-10 $\mathrm{cm}+$ chisel 20-22 $\mathrm{cm}$ ); surface tillage (disking) up to $8 \mathrm{~cm}$; direct sowing (No-till). The No-till variant was carried out without any tillage, by a direct sowing with a drill Don 114. Tillage practices were applied systematically beginning from 2015 for each variant. Mineral fertilizers were not applied.

The variants in the field experiment were placed systematically in one tier. The area of the sowing plot was $6000 \mathrm{~m}^{2}(60 \times 100)$, the replication was three-fold.

The research was carried out on winter wheat (Triticum aestivum) of the Nemchinovskaya 17 variety. The technology of winter wheat cultivation was generally accepted for the region and did not differ except for the primary tillage. The soil of the experimental site was a typical thick heavy-loamy chernozem. The average content of humus in the arable layer was $5.3 \%$, those of mobile phosphorus and exchangeable potassium

\footnotetext{
${ }^{*}$ Corresponding author: dubovikdm@yandex.ru
} 
(analyzed by Chirikov method) were 185 and $128 \mathrm{mg} / \mathrm{kg}$ of soil, respectively. The reaction of the soil medium was slightly acidic $\left(\mathrm{pH}_{\mathrm{KCl}} 5.4\right)$.

The assessment of the reserves of crop root residues in the arable layer was carried out by the soil drilling method with subsequent washing [9]. Determination of nitrogen, phosphorus and potassium in root residues, straw and grain was carried out by the method of K.E. Ginzburg [10]. Statistical processing of the obtained data was carried out using Microsoft Excel, Statistica, and methods of variance and regression analyses.

\section{Results and discussion}

The content of undecayed plant residues in winter wheat in the spring period in the $0-20 \mathrm{~cm}$ layer in case of plowing was less by 2.6-3.0 t/ha than in case of other studied tillage methods (Table 1).

Table 1. Content of undecayed plant residues in the soil

\begin{tabular}{|c|c|c|c|c|}
\hline $\begin{array}{l}\text { Primary } \\
\text { Tillage } \\
\text { Practice }\end{array}$ & $\begin{array}{l}\text { Depth, } \\
\text { cm }\end{array}$ & $\begin{array}{l}\text { Plant } \\
\text { Residue } \\
\text { Weight } \\
\text { in } \\
\text { Spring, } \\
\text { t/ha }\end{array}$ & $\begin{array}{c}\text { Plant } \\
\text { Residue } \\
\text { Weight in } \\
\text { Harvesting } \\
\text { Time, } t / \text { ha }\end{array}$ & $\begin{array}{l}\text { Accumulation } \\
\text { of Residues } \\
\text { during the } \\
\text { Growing } \\
\text { Season, } \mathrm{t} / \mathrm{ha}\end{array}$ \\
\hline \multirow{2}{*}{ Plowing } & $0-10$ & 6.58 & 10.37 & 3.79 \\
\hline & $10-20$ & 8.93 & 9.76 & 0.83 \\
\hline \multirow{2}{*}{$\begin{array}{l}\text { Combined } \\
\text { tillage }\end{array}$} & $0-10$ & 10.38 & 12.75 & 2.37 \\
\hline & $10-20$ & 7.96 & 8.39 & 0.42 \\
\hline \multirow{2}{*}{$\begin{array}{l}\text { Surface } \\
\text { tillage }\end{array}$} & $0-10$ & 11.19 & 13.21 & 2.01 \\
\hline & $10-20$ & 7.32 & 8.27 & 0.95 \\
\hline \multirow{2}{*}{$\begin{array}{l}\text { Direct } \\
\text { sowing }\end{array}$} & $0-10$ & 11.53 & 15.49 & 3.96 \\
\hline & $10-20$ & 6.56 & 7.14 & 0.57 \\
\hline \multirow{2}{*}{$\mathrm{LSD}_{05}$} & tillage & 0.18 & 0.81 & 0.03 \\
\hline & depth & 0.13 & 0.58 & 0.02 \\
\hline
\end{tabular}

Moreover, in the upper $0-10 \mathrm{~cm}$ layer, their greatest amount was noted with direct sowing $-11.53 \mathrm{t} / \mathrm{ha}$, which was more by $0.34 \mathrm{t} / \mathrm{ha}$ than with surface tillage, by 1.15 $\mathrm{t} / \mathrm{ha}$ than with combined tillage, and by $4.95 \mathrm{t} / \mathrm{ha}$ than with plowing. During the moldboard plowing, the content of plant residues in the soil in the $0-10 \mathrm{~cm}$ layer was less than in the $10-20 \mathrm{~cm}$ layer by $2.35 \mathrm{t} / \mathrm{ha}$. In case of subsurface methods of primary tillage, there were more of them in the upper $0-10 \mathrm{~cm}$ layer than in the lower $10-20 \mathrm{~cm}$ layer by $2.42-4.97 \mathrm{t} / \mathrm{ha}$, and the greatest difference was in direct sowing.

After harvesting winter wheat, there was a natural increase in the amount of plant residues in the soil due to the newly formed mass of roots. At the same time, on the plowed land the mass of undecayed plant residues was evenly distributed over the $0-20 \mathrm{~cm}$ layer $(51.5 \%$ in the upper layer and $48.5 \%$ in the lower one), while with an increase in the degree of minimization of primary tillage, their share in the $0-10 \mathrm{~cm}$ layer increased $(60.3 \%$ for combined, $61.5 \%$ for surface tillage, and $68.4 \%$ for direct sowing). But, at the same time, the greatest increase in the content of plant residues in the soil was observed in extremely opposite variants, i.e. with plowing (by $4.62 \mathrm{t} / \mathrm{ha}$ ) and with direct sowing (by 4.53 $\mathrm{t} / \mathrm{ha}$ ). This was due to the fact that when plowing was used a larger amount of plant biomass was formed, and with direct sowing the processes of its decomposition slowed down.

Plant residues serve as a source of entering the soil of such basic macronutrients as nitrogen, phosphorus and potassium. The nitrogen content in plant residues in the spring period, on the average for the arable layer, changed significantly only with direct sowing and was higher by $0.11-0.14 \%$ than with other tillage practices (Table 2). By the harvesting period, the amount of nitrogen in the plant residues decreased on the average by $0.11-0.25 \%$. With all the methods of primary tillage, both in spring and at the time of harvesting, the highest nitrogen content in the plant residues was in the layer of $0-10 \mathrm{~cm}$. The phosphorus content in the plant residues, both in spring and during harvesting, in the variants of plowing, combined and surface tillage, did not change significantly, and was $0.31-0.36 \%$. With direct sowing the amount of phosphorus increased to $0.41-0.45 \%$ in spring and to $0.38 \%$ by the time of harvesting. The potassium content in the plant residues was approximately the same for all the studied methods of primary tillage, regardless of the soil layer, and was $0.42-0.44 \%$.

Table 2. Macronutrient content in undecayed plant residues

\begin{tabular}{|c|c|c|c|c|c|c|c|}
\hline \multirow{2}{*}{$\begin{array}{c}\text { Primary Tillage } \\
\text { Practice }\end{array}$} & \multirow{2}{*}{ Layer, $\mathrm{cm}$} & \multicolumn{2}{|c|}{$\mathrm{N}, \%$} & \multicolumn{2}{|c|}{$\mathrm{P}_{2} \mathrm{O}_{5}, \%$} & \multicolumn{2}{|c|}{$\mathrm{K}_{2} \mathrm{O}, \%$} \\
\hline & & spring & harvest & spring & harvest & spring & harvest \\
\hline \multirow{2}{*}{ Plowing } & $0-10$ & 1.18 & 1.01 & 0.36 & 0.33 & 0.44 & 0.53 \\
\hline & $10-20$ & 1.12 & 0.95 & 0.31 & 0.34 & 0.44 & 0.56 \\
\hline \multirow{2}{*}{ Combined tillage } & $0-10$ & 1.24 & 1.18 & 0.34 & 0.33 & 0.42 & 0.53 \\
\hline & $10-20$ & 1.06 & 0.81 & 0.33 & 0.33 & 0.44 & 0.53 \\
\hline \multirow{2}{*}{ Surface tillage } & $0-10$ & 1.15 & 1.14 & 0.32 & 0.33 & 0.44 & 0.53 \\
\hline & $10-20$ & 1.09 & 0.90 & 0.32 & 0.32 & 0.44 & 0.56 \\
\hline \multirow{2}{*}{ Direct sowing } & $0-10$ & 1.34 & 1.23 & 0.45 & 0.38 & 0.44 & 0.56 \\
\hline & $10-20$ & 1.18 & 0.84 & 0.41 & 0.38 & 0.42 & 0.53 \\
\hline \multirow{2}{*}{$\mathrm{LSD}_{05}$} & tillage & 0.14 & 0.11 & 0.05 & 0.02 & 0.04 & 0.06 \\
\hline & depth & 0.10 & 0.13 & 0.03 & 0.01 & 0.03 & 0.04 \\
\hline
\end{tabular}


Table 3. Reserves of nutrients in undecayed plant residues

\begin{tabular}{|c|c|c|c|c|c|c|c|c|c|c|}
\hline \multirow{2}{*}{$\begin{array}{c}\text { Primary Tillage } \\
\text { Practice }\end{array}$} & \multirow{2}{*}{ Layer, cm } & \multicolumn{3}{|c|}{$\mathrm{N}, \mathrm{kg} / \mathrm{ha}$} & \multicolumn{3}{|c|}{$\mathrm{P}_{2} \mathrm{O}_{5}, \mathrm{~kg} / \mathrm{ha}$} & \multicolumn{3}{|c|}{$\mathrm{K}_{2} \mathrm{O}, \mathrm{kg} / \mathrm{ha}$} \\
\hline & & $1 *$ & 2 & 3 & 1 & 2 & 3 & 1 & 2 & 3 \\
\hline \multirow{2}{*}{ Plowing } & $0-10$ & 77.6 & 104.7 & 27.1 & 23.7 & 34.2 & 10.5 & 28.9 & 54.9 & 26.0 \\
\hline & $10-20$ & 100.0 & 92.7 & -7.3 & 27.7 & 33.2 & 5.5 & 39.3 & 54.6 & 15.4 \\
\hline \multirow{2}{*}{ Combined tillage } & $0-10$ & 128.9 & 150.5 & 22.1 & 35.3 & 42.1 & 6.8 & 43.6 & 67.6 & 24.0 \\
\hline & $10-20$ & 84.4 & 67.9 & -16.5 & 26.3 & 27.7 & 1.4 & 35.0 & 44.5 & 9.4 \\
\hline \multirow{2}{*}{ Surface tillage } & $0-10$ & 128.7 & 150.6 & 21.9 & 35.8 & 43.6 & 7.8 & 49.3 & 70.0 & 20.7 \\
\hline & $10-20$ & 79.8 & 74.4 & -5.4 & 23.4 & 26.5 & 3.0 & 32.2 & 46.3 & 14.1 \\
\hline \multirow{2}{*}{ Direct sowing } & $0-10$ & 154.5 & 190.5 & 36.0 & 51.9 & 58.9 & 7.0 & 50.7 & 86.7 & 36.0 \\
\hline & $10-20$ & 77.4 & 59.9 & -17.5 & 26.9 & 27.1 & 0.2 & 27.6 & 37.8 & 10.3 \\
\hline \multirow{2}{*}{$\mathrm{LSD}_{05}$} & tillage & 9.5 & 11.0 & - & 2.7 & 2.8 & - & 3.3 & 7.7 & - \\
\hline & depth & 6.7 & 7.8 & - & 1.9 & 2.1 & - & 2.3 & 54 & - \\
\hline
\end{tabular}

*1 - spring period, 2 - harvesting time, 3 - nutrient balance in plant residues

By the harvesting period, the amount of potassium in the plant residues increased on the average by 0.09 $0.12 \%$, but there were no significant differences in the tillage methods studied.

Table 4. Macronutrient content in winter wheat straw

\begin{tabular}{|c|c|c|c|c|c|c|c|}
\hline \multirow{2}{*}{$\begin{array}{l}\text { Primary } \\
\text { Tillage } \\
\text { Practice } \\
\end{array}$} & \multirow{2}{*}{$\begin{array}{l}\text { Stra } \\
\text { W, } \\
\text { t/ha }\end{array}$} & \multicolumn{2}{|c|}{$\mathrm{N}$} & \multicolumn{2}{|c|}{$\mathrm{P}_{2} \mathrm{O}_{5}$} & \multicolumn{2}{|c|}{$\mathrm{K}_{2} \mathrm{O}$} \\
\hline & & $\%$ & $\begin{array}{l}\mathrm{kg} / \\
\mathrm{ha}\end{array}$ & $\%$ & $\begin{array}{l}\mathrm{kg} / \\
\mathrm{ha}\end{array}$ & $\%$ & $\begin{array}{l}\mathrm{kg} / \\
\mathrm{ha}\end{array}$ \\
\hline Plowing & 6,2 & 0.56 & 34.7 & 0.26 & 16.1 & 1.10 & 68.2 \\
\hline $\begin{array}{l}\text { Combi- } \\
\text { ned } \\
\text { tillage }\end{array}$ & 5,8 & 0.56 & 32.5 & 0.23 & 13.3 & 0.98 & 56.8 \\
\hline $\begin{array}{l}\text { Surface } \\
\text { tillage }\end{array}$ & 3,8 & 0.56 & 21.3 & 0.22 & 8.4 & 0.91 & 34.6 \\
\hline $\begin{array}{l}\text { Direct } \\
\text { sowing }\end{array}$ & 3,6 & 0.56 & 20.2 & 0.24 & 8.6 & 0.83 & 29.9 \\
\hline $\mathrm{LSD}_{05}$ & 0,2 & 0.02 & 0.3 & 0.02 & 0.3 & 0.03 & 0.4 \\
\hline
\end{tabular}

As a result of determining the amount of macronutrients in the plant residues, their reserves were determined (Table 3). It was found that during the active growing season of winter wheat, there was an increase in the nitrogen reserves in the plant residues in a layer of 0 $10 \mathrm{~cm}$. The most significant increase in the nitrogen reserves in this soil layer occurred during direct sowing, i.e. $+36.0 \mathrm{~kg} / \mathrm{h}$. In a layer of $10-20 \mathrm{~cm}$, there was a decrease in the nitrogen reserves by the harvest period compared to the spring period, and it was also most active with direct sowing. Obviously, that type of change in the nitrogen reserves in the plant residues in the soil layers was associated with microbiological activity, the highest degree of decomposition of the plant residues, and the fixation of the nitrogen released from them by the soil.

The phosphorus reserves in the soil increased by the harvesting period, both in the $0-10 \mathrm{~cm}$ layer and in the $10-20 \mathrm{~cm}$ layer with all the studied tillage methods. At the same time, the increase in the phosphorus reserves in the $0-10 \mathrm{~cm}$ layer was significantly higher than in the 10 $20 \mathrm{~cm}$ layer. This was due to a decrease in the phosphate sorption capacity of the soil during the release of phosphorus from decomposing residues and an increase in the amount of inorganic phosphorus [11]. The greatest reserves of phosphorus in the plant residues were observed in case of plowing.

Potassium reserves in the plant residues increased on the average by33.4-46.3 kg/ha by the harvest period. In the $0-10 \mathrm{~cm}$ layer, the potassium reserves were $1.47-3.50$ times higher than in the $10-20 \mathrm{~cm}$ layer. The largest reserves of potassium were observed with direct sowing, and minimal reserves with combined tillage.

Straw also enters the soil as plant residues along with plant roots. Against the background of plowing, the largest mass of winter wheat straw was formed, i.e. 6.2 $\mathrm{t} / \mathrm{ha}$ (Table 4). With the minimization of the primary tillage, the amount of straw decreases, from the $3.6 \mathrm{t} / \mathrm{ha}$ minimum with direct sowing. At the same time, the nitrogen content in the straw did not depend on the tillage practice, and was the same $0.56 \%$. The phosphorus content also did not differ significantly and was $0.22-0.26 \%$. The content of potassium in the straw was the highest against the background of plowing, i.e. $1.10 \%$ and with a decrease in the tillage depth it decreased to $0.83 \%$ with direct sowing.

The reserves of macronutrients coming with winter wheat straw were calculated. The greatest amount of nitrogen, phosphorus and potassium with straw came when plowing was used as a primary tillage practice (34.7, 16.1 and $68.2 \mathrm{~kg} / \mathrm{ha}$, respectively). As the tillage is minimized, the amount of macronutrients that can be introduced with the straw decreases, which is primarily due to the mass of straw formed.

Table 5. Content of nutrients in winter wheat grain

\begin{tabular}{|c|c|c|c|c|c|c|c|}
\hline \multirow{2}{*}{$\begin{array}{c}\text { Primary } \\
\text { Tillage } \\
\text { Practice }\end{array}$} & \multirow{2}{*}{$\begin{array}{l}\text { Yiel } \\
\text { d, } \\
\text { t/ha }\end{array}$} & \multicolumn{2}{|l|}{$\mathrm{N}$} & \multicolumn{2}{|c|}{$\mathrm{P}_{2} \mathrm{O}_{5}$} & \multicolumn{2}{|l|}{$\mathrm{K}_{2} \mathrm{O}$} \\
\hline & & $\%$ & $\begin{array}{l}\mathrm{kg} / \mathrm{h} \\
\mathrm{a}\end{array}$ & $\%$ & $\begin{array}{l}\mathrm{kg} / \mathrm{h} \\
\mathrm{a}\end{array}$ & $\%$ & $\begin{array}{l}\mathrm{kg} / \mathrm{h} \\
\mathrm{a}\end{array}$ \\
\hline Plowing & 4,40 & 2,21 & 97,2 & 0,92 & 40,5 & 0,60 & 26,4 \\
\hline $\begin{array}{l}\text { Combine } \\
\text { d tillage }\end{array}$ & 4,00 & 1,90 & 76,0 & 0,84 & 33,6 & 0,53 & 21,2 \\
\hline $\begin{array}{l}\text { Surface } \\
\text { tillage }\end{array}$ & 3,75 & 2,18 & 81,8 & 0,75 & 28,1 & 0,50 & 18,8 \\
\hline $\begin{array}{l}\text { Direct } \\
\text { sowing }\end{array}$ & 3,26 & 1,96 & 63,9 & 0,83 & 27,1 & 0,53 & 17,3 \\
\hline $\mathrm{LSD}_{05}$ & 0,11 & 0,02 & 1,2 & 0,03 & 0,4 & 0,02 & 0,2 \\
\hline
\end{tabular}


Table 6. Balance of macronutrients

\begin{tabular}{|c|c|c|c|c|c|c|c|c|}
\hline \multirow[b]{2}{*}{$\begin{array}{c}\text { Primary Tillage } \\
\text { Practice }\end{array}$} & \multicolumn{6}{|c|}{ Input } & \multirow[b]{2}{*}{$\begin{array}{c}\text { Consumption } \\
\text { Removal by } \\
\text { Grain } \\
\text { Harvest, } \\
\text { kg/ha }\end{array}$} & \multirow[b]{2}{*}{$\begin{array}{c}\text { Balance } \pm, \\
\mathrm{kg} / \mathrm{ha}\end{array}$} \\
\hline & $\begin{array}{l}\text { Input } \\
\text { with } \\
\text { Seeds, } \\
\mathrm{kg} / \mathrm{ha}\end{array}$ & $\begin{array}{l}\text { Input with } \\
\text { Plant } \\
\text { Residues, } \\
\text { kg/ha }\end{array}$ & $\begin{array}{l}\text { Input } \\
\text { with } \\
\text { Straw, } \\
\mathrm{kg} / \mathrm{ha}\end{array}$ & $\begin{array}{c}\Sigma \text { Plant } \\
\text { Residues } \\
+ \text { Straw, } \\
\text { kg/ha }\end{array}$ & $\begin{array}{l}\text { Conversion to \% } \\
\text { of Use from } \\
\text { Crop-Root } \\
\text { Residues, } \mathrm{kg} / \mathrm{ha} \\
(15 \%)\end{array}$ & $\begin{array}{l}\text { Total } \\
\text { Input, } \\
\text { kg/ha }\end{array}$ & & \\
\hline \multicolumn{9}{|c|}{ Nitrogen } \\
\hline Plowing & 5.2 & 19.8 & 34.7 & 54.5 & 8.2 & 13.4 & 97.2 & -83.8 \\
\hline $\begin{array}{l}\text { Combined } \\
\text { tillage }\end{array}$ & 5.2 & 5.6 & 32.5 & 38.1 & 5.7 & 10.9 & 76.0 & -65.1 \\
\hline Surface tillage & 5.2 & 16.5 & 21.3 & 37.8 & 4.2 & 9.4 & 81.8 & -72.4 \\
\hline Direct sowing & 5.2 & 18.5 & 20.2 & 38.7 & 5.8 & 11.0 & 63.9 & -52.9 \\
\hline \multicolumn{9}{|c|}{ Phosphorus } \\
\hline Plowing & 2.1 & 16.0 & 40.5 & 56.5 & 8.5 & 10.6 & 40.5 & -29.9 \\
\hline $\begin{array}{l}\text { Combined } \\
\text { tillage }\end{array}$ & 2.1 & 8.2 & 33.6 & 41.8 & 6.3 & 8.4 & 33.6 & -25.2 \\
\hline Surface tillage & 2.1 & 10.8 & 28.1 & 38.9 & 5.8 & 7.9 & 28.1 & -20.2 \\
\hline Direct sowing & 2.1 & 7.2 & 27.1 & 34.3 & 5.1 & 7.2 & 27.1 & -19.9 \\
\hline \multicolumn{9}{|c|}{ Potassium } \\
\hline Plowing & 1.4 & 41.4 & 68.2 & 109.6 & 16.4 & 17.8 & 26.4 & -8.6 \\
\hline $\begin{array}{l}\text { Combined } \\
\text { tillage }\end{array}$ & 1.4 & 33.4 & 56.8 & 90.2 & 13.5 & 14.9 & 21.2 & -7.7 \\
\hline Surface tillage & 1.4 & 34.8 & 34.6 & 69.4 & 10.4 & 11.8 & 18.8 & -8.4 \\
\hline Direct sowing & 1.4 & 46.3 & 29.9 & 76.2 & 11.4 & 12.8 & 17.3 & -5.9 \\
\hline
\end{tabular}

Winter wheat grain is a commodity part that is irrevocably removed from the field and together with it the main macronutrients are taken out. To compensate for these losses, it is necessary to have an idea of the number of nutrients taken out. The highest yield of winter wheat grain of $4.40 \mathrm{t} / \mathrm{ha}$ was obtained against the background of plowing, and the lowest yield of $3.26 \mathrm{t} / \mathrm{ha}$ with direct sowing (Table 5). In winter wheat grain, the highest nitrogen content of $2.21 \%$ was noted in case of plowing, and the lowest content of $1.90 \%$ in case of combined tillage. The content of phosphorus and potassium in the grain was also the highest during plowing, $0.92 \%$ and $0.60 \%$, respectively. The minimum amount of phosphorus and potassium was observed in the grain obtained against the background of surface tillage, $0.75 \%$ and $0.50 \%$, respectively.

The removal of macronutrients from winter wheat grain was calculated. With the maximum yield on the background of plowing, it was natural that the removal of nitrogen, phosphorus and potassium was the highest here, 97.2, 40.5 and $26.4 \mathrm{~kg} / \mathrm{ha}$, respectively. The minimum removal of nutrients from the grain was observed with direct sowing.

Having data on the amount of nutrients entering the soil with plant residues, as well as the removal of grain, it is possible to make a forecast on the balance of nitrogen, phosphorus and potassium in the arable layer of the soil $(0-20 \mathrm{~cm})$. At the same time, it was assumed that the use of nitrogen, phosphorus and potassium from plant residues is approximately $15 \%$.

The calculation of the balance of nutrients shows that without applied fertilizers, with all the studied practices of primary tillage, the balance is negative (Table 6). At the same time, maximum deficit of macronutrients was formed in case of plowing. Thus, for nitrogen, it was
1.29 times higher than with combined tillage, 1.16 times higher than with surface tillage, and 1.58 times higher than with direct sowing. Phosphorus deficiency was also greatest in plowing - 1.19-1.50 times more than in other tillage practices. The lack of potassium was noted in much smaller amounts than that of nitrogen and phosphorus $5.9-8.6 \mathrm{~kg} / \mathrm{ha}$. At the same time, it was minimum against the background of direct sowing, and with other tillage practices it did not differ significantly.

\section{Conclusion}

It was found that in the spring period in winter wheat crops in the soil layer of $0-20 \mathrm{~cm}$ with subsurface practices of primary tillage (combined and surface tillage), as well as direct sowing, there were more undecayed plant residues than with the moldboard plowing. At the same time, as the depth of tillage decreases, a large mass of plant residues is concentrated in the upper $0-10 \mathrm{~cm}$ soil layer. By the harvest period, there is an increase in the amount of plant residues in the soil. At the same time, the highest indicators are noted on plowing and direct sowing.

The greatest reserves of nitrogen and potassium in undecayed plant residues in the soil under winter wheat were found in the variant with direct sowing, phosphorus in that of plowing in the soil layer of $0-10 \mathrm{~cm}$.

A higher mass of winter wheat straw was formed against the background of plowing, and the content of phosphorus and potassium in it was the highest. Due to the higher yield of the vegetative mass of winter wheat, the amount of macronutrients supplied with the mass of straw in this case was the highest.

The highest yield of winter wheat grain was formed against the background of plowing, the lowest yield with 
direct sowing. In winter wheat grain, the maximum amount of nitrogen, phosphorus and potassium was accumulated during its cultivation with plowing.

Without the use of mineral fertilizers, a negative balance of macronutrients is formed. At the same time, it reaches the highest values when plowing is used as primary tillage method, and they are the lowest with direct sowing.

\section{References}

1. V.I. Turusov, O.A. Abanina, O.A. Bogatyh, Probl. agrohim. i ekolog. 248 (2019)

2. A.K. Svechnikov, Agrar. nauka Evro-SeveroVostoka. 6613 (2019)

3. B. Ghimire, R. Ghimire, D. VanLeeuwen, A. Mesbah, Sustainab. 92316 (2017)

4. J. Zhang, X. Wang, J. Wang, W. Wang, Jour. of Integ. Agricult. 13648 (2014)

5. R.D. Bardgett, L. Mommer, F.T. De Vries, Trends Ecol. Evol. 29692 (2014)

6. S. Torma, J. Vilček, T. Lošak, S. Kužel, A. Martensson, Acta Agricult. Scand., Section B - Soil \& Plant Sci. 68358 (2018)

7. E.N. Efremova, Vest. Altajsk. GAU. 428 (2014)

8. V.I. Kiryushin, Zemled. 73 (2013)

9. I.P. Vasiliev, A.M. Tulikov, G.I. Bazdyrev rt al. Laboratory Manual for Agronomy (KolosS, 2004)

10. V.G. Mineev, V.G. Sychev, O.A. Amelianchik et al. Laboratory Manual on Agrochemistry (MSU Russian, 2001)

11. R.J. Haynes, M.S. Mokolobate, Nutr. Cycl. in Agroecosyst. 147 (2001) 